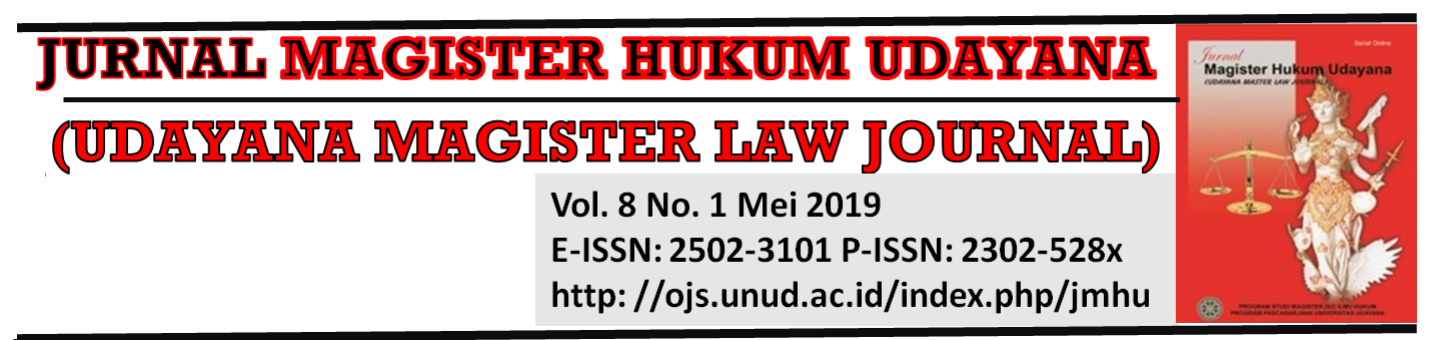

\title{
Penertiban Bangunan Tanpa Izin yang Berdiri di Atas Tanah Negara pada Sempadan Sungai Limpok Aceh Besar
}

\author{
Putri Tasya Fabyolla ${ }^{1}$, Ilyas Ismail ${ }^{2}$, M.Nur Rasyid ${ }^{3}$ \\ 1Program Studi Magister Ilmu Hukum Universitas Syiah Kuala, Aceh, \\ E-mail: putritasyafabyolla@yahoo.com \\ ${ }^{2}$ Fakultas Hukum Universitas Syiah Kuala, Aceh, \\ E-mail: ilyas.ismail@gmail.com \\ ${ }^{3}$ Fakultas Hukum Universitas Syiah Kuala, Aceh, \\ E-mail: mnurrasyid@unsyiah.ac.id
}

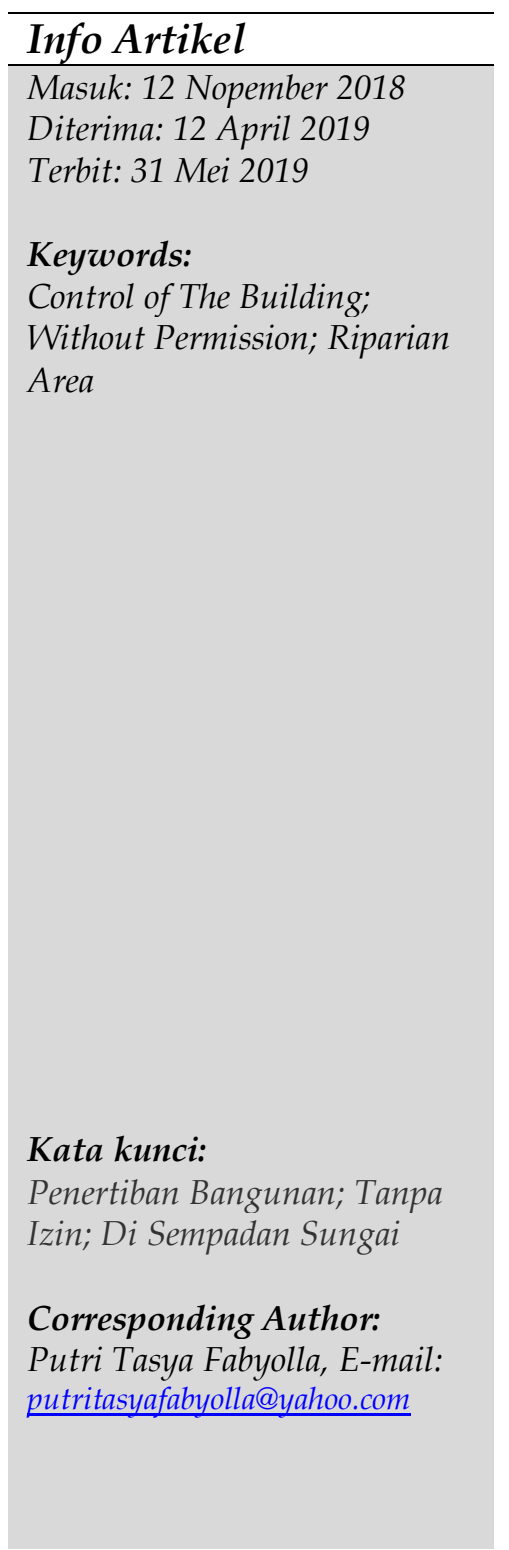

\begin{abstract}
The prohibition of building buildings in river border areas is regulated in Article 22 Paragraph (2) Regulation of the Minister of Public Works and Public Housing Number 28 / PRT / M / 2015 concerning the Determination of Borders of Rivers and Lake Borders. It is stated that it is forbidden to build buildings, except building with certain functions. In reality, there are a number of buildings that stand in the river border area of Limpok Village, Aceh Besar District. The method of this research is empirical juridical research using a conceptual approach. The results of the research in the field is there are buildings that stand without permits in the river border area of the big village of Limpok, Aceh Regency. Initially, the community was given the opportunity to use the country's land to grow crops that were not hard. However, they transferred the utilization by building a building on it, so the building that stood on the land had no legality. It is clear that each building that stands must follow the licensing stage first so the building has the legality of a building permit. The factor that became the government's issues in carrying out control was the lack of budget in the field, secondly, it was indicated that the community made land payments by the village head (geuchik). The government must take strict legal action against the village head (geuchik) who plays in the area. Law enforcement does not need tolerance, so rules are not violated.
\end{abstract}

\begin{tabular}{l}
\hline Abstrak \\
\hline Ketentuan larangan mendirikan bangunan di kawasan sempadan \\
sungai diatur pada Pasal 22 Ayat (2) Peraturan Menteri \\
Pekerjaan Umum Dan Perumahan Rakyat Nomor \\
28/PRT/M/2015 Tentang Penetapan Garis Sempadan Sungai \\
Dan Sempadan Danau. Dimana disebutkan dilarang mendirikan \\
bangunan, kecuali bangunan prasarana sumber daya air, fasilitas \\
jembatan dan dermaga, jalur pipa gas dan air minum, rentangan \\
kabel listrik dan telekomunikasi, dan bangunan \\
ketenagalistrikan. Namun pada kenyataannya terdapat sejumlah \\
bangunan yang berdiri di kawasan sempadan sungai Desa
\end{tabular}


DOI:

10.24843/JMHU.2019.v08.i01. p09

\section{Pendahuluan}

Di Indonesia ketentuan-ketentuan pokok tentang pertahanan telah diatur dalam Undang-Undang Nomor 5 Tahun 1960 Tentang Peraturan Dasar Pokok-pokok Agraria, Lembaga Negara (LN) Republik Indonesia Tahun 1960 Nomor 104 Agraria, Lembaran Negara (LN) Republik Indonesia Tahun 1960 - 140 Tambahan Lembaran Negara (TLN) Republik Indonesia Nomor 2043. Muchsin (2011) menyatakan bahwa tujuan UUPA adalah untuk kemakmuran rakyat. Hal ini sesuai dengan tujuan berbangsa dan bernegara, yaitu agar terwujudnya kesejahteraan rakyat. ${ }^{1}$

Terdapat beberapa ahli hukum yang mendefinisikan arti hukum agraria. E. Utrecht (dalam Limbong,2012) mengatakan hukum agraria adalah bagian dari hukum administrasi negara, yaitu hukum agraria dan hukum tanah menjadi bagian dari hukum administrasi negara, yang memiliki hubungan hukum istimewa dimana diadakan hingga memungkinkan para pejabat yang bertugas mengurus soal-soal agraria. $^{2}$

Dalam negara hukum, peranan hukum diperlukan sebagai pembatasan terhadap kekuasaan negara dan politik yang tidak dapat dilanggar oleh siapapun. Hal ini kemudian memunculkan istilah pemerintah dibawah hukum (goverment under the law). ${ }^{3}$

Ketentuan-ketentuan mengenai pertanahan di Indonesia diatur oleh pemerintah dengan tujuan agar terciptanya kesejahteraan rakyat, tentunya sebagai aturan yang membatasi hak dan kewajiban terhadap penggunaan tanah di Indonesia khususnya. Dengan adanya aturan-aturan tersebut, masyarakat Indonesia wajib tunduk terhadap aturan-aturan yang berlaku.

1 Santoso, U. (2013). Kewenangan Pemerintah Daerah dalam Penguasaan Atas Tanah. Jurnal Dinamika Hukum, 13(1), 99-108.

2 Limbong, B. (2012). Hukum Agraria Nasional, Jakarta: Margaretha Pustaka, h.51 .

3 Fuady, M, (2011). Teori Negara Hukum Modern Rechtstaat, Bandung : PT. Reflika Aditama. h.1. 
Menurut Subekti dan R. Tjitrosoedibio dalam buku karangan Urip santoso dimana disebutkan bahwa agraria adalah urusan tanah dan segala apa yang ada di dalamnya (misalnya batu, kerikil, dan tambang) dan di atasnya (tanaman dan bangunan). ${ }^{4}$

Sebagaimana disebutkan Moeljono dkk (2018) yang dikutip dalam buku Boedi Harsono disebutkan bahwa :

Semua hak penguasaan atas tanah berisi serangkaian wewenang, kewajiban, dan/atau larangan bagi pemegang haknya untuk berbuat sesuatu mengenai tanah yang dihaki. "sesuatu" yang boleh, wajib atau dilarang untuk berbuat, yang merupakan isi Hak penguasaan atas itulah yang menjadi kriteria atau tolak pembeda di antara hak-hak penguasaan atas tanah dalam Hukum Tanah. ${ }^{5}$

Hak menguasai negara atas tanah diatur dalam Pasal 2 UUPA, dimana disebutkan negara diberikan wewenang :

a. Mengatur dan menyelenggarakan peruntukan, penggunaan, persediaan dan pemeliharaan bumi, air, dan ruang angkasa tersebut;

b. Menentukan dan mengatur hubungan-hubungan hukum antara orang-orang dengan bumi, air, dan ruang angkasa;

c. Menentukan dan mengatur hubungan-hubungan hukum antara orang-orang dan perbuatan-perbuatan hukum yang mengenai bumi, air, dan ruang angkasa. ${ }^{1}$

Berdasarkan ketentuan dari Pasal 2 Ayat (2) UUPA diatas, bahwa negara memberikan kebebasan kepada masyarakat untuk memanfaatkan tanah negara termasuk mendirikan bangunan di atasnya, namun tentunya dalam kegiatan tersebut pemerintah membatasi dengan menentukan syarat-syarat yang harus dipenuhi oleh masyarakat jika hendak memanfaatkan tanah negara dengan mendirikan bangunan di atasnya. Adapun salah satunya yaitu dengan mengajukan permohonan izin terhadap pemerintah daerah.

Adapun ketentuan Pasal 2 Peraturan Pemerintah Pengganti Undang-Undang Nomor 51 Tahun 1960 Tentang Larangan Pemakaian Tanah Tanpa Izin Yang Berhak Atau Kuasanya berbunyi bahwa dilarang memakai tanah tanpa izin yang berhak atau kuasanya yang sah. Kemudian Pasal 3 Ayat (1) berbunyi bahwa penguasaan daerah dapat mengambil tindakan-tindakan untuk menyelesaikan pemakaian tanah yang bukan perkebunan dan bukan hutan tanpa izin yang berhak atau kuasanya yang sah, yang ada di daerahnya masing-masing pada suatu waktu. Selanjutnya Pasal 3 Ayat (2) berbunyi bahwa penyelesaian yang tersebut pada ayat (1) yaitu dapat dinilai dengan memperhatikan rencana peruntukan dan penggunaan tanah yang bersangkutan.

Bangunan gedung sebagai tempat manusia melakukan kegiatannya, mempunyai peranan yang sangat strategis dalam pembentukan watak, perwujudan produktivitas, dan jati diri manusia. Oleh karena itu, penyelenggaraan bangunan gedung perlu diatur dan dibina demi kelangsungan dan peningkatan kehidupan serta penghidupan masyarakat, sekaligus untuk mewujudkan bangunan gedung yang fungsional, andal, berjati diri, serta seimbang, serasi dan selaras dengan lingkungannya.

4 Santoso, U. (2009). Hukum Agraria dan Hak-hak Atas Tanah. Jakarta: Kencana, h.73-75.

5 Moeljono, M., Koeswahyono, I., Widiarto, A. E., Sutoyo, S., \& Mualiffien, D. M. (2012). Kajian Yuridis Tentang Pengelolaan Tanah Penguasaan Pemerintah Kota Malang Yang Disewa Oleh Pihak Ketiga. Jurnal Hukum E Pembangunan, 42(2), h.190. 
Hardiyansyah (2012) dalam tulisannya mengatakan bahwa pemerintah memiliki kewenangan dalam menghentikan proses pembangunan yang dianggap "liar" dan tidak legal. ${ }^{6}$

Dalam Hukum Administrasi, izin merupakan instrumen yuridis yang digunakan oleh pemerintah untuk mempengaruhi para warga agar mau mengikuti cara yang dianjurkan guna mencapai suatu tujuan konkrit. Sebagai suatu instrument hukum, izin berfungsi sebagai ujung tombak atau alat yang bertujuan untuk mengarahkan, mengendalikan, merekayasa, dan merancang masyarakat adil makmur. melalui izin dapat diketahui bagaimana gambaran masyarakat adil makmur itu terwujud, yang berarti persyaratan-persyaratan yang terkandung dalam izin merupakan pengendali dalam memfungsikan izin itu sendiri.

Dalam negara hukum, tugas dan wewenang pemerintah tidak hanya sekedar menjaga ketertiban dan keamanan, namun juga mengupayakan kesejahteraan umum. Dalam rangka melaksanakan tugas tersebut kepada pemerintah diberikan kewenangan dalam bidang pengaturan, yang berfungsi memunculkan beberapa instrumen yuridis untuk menghadapi peristiwa individual dan konkret, yaitu dalam bentuk ketetapan. Sesuai dengan sifatnya, individual dan konkret. Ketetapan merupakan awal mula dari instrumen hukum dalam penyelenggaraan pemerintah, atau sebagai norma penutup dalam rangkaian norma hukum. ${ }^{7}$ Asas legalitas merupakan salah satu unsur dari negara hukum. Unsur lainnya adalah kesamaan di hadapan hukum (equality before the law), dan rasa keadilan serta kemanusiaan, baik dari rakyat maupun dari pemimpinnya (constitution based on human rights). ${ }^{8}$

Pada masa lampau, seperti yang kita ketahui pada umumnya proses pemanfaatan sumber daya alam seringkali ditujukan untuk kepentingan tertentu tanpa memikirkan dampak yang ditimbulkan. Hal ini seringkali menyebabkan kerusakan dan pencemaran lingkungan yang sesungguhnya memiliki dampak lebih besar dari pada keuntungan yang diperoleh. Tentu saja hal ini sangat berbahaya sehingga dibutuhkan aturan yang dapat menahan kerusakan lebih besar.

Segala sesuatu di dunia ini erat hubungannya satu dengan yang lain. Mengenai hal ini koesnadi Hardjasoemantri mengatakan bahwa antara manusia dengan manusia, antara manusia dengan hewan, antara manusia dengan tumbuh-tumbuhan, dan bahkan antara manusia dengan benda mati sekalipun. Demikian juga dengan hewan. ${ }^{9}$ Oleh sebab itu, segala sesuatu yang dilakukan oleh manusia perlu adanya pembatasan yang dilakukan yaitu melalui instrumen perizinan yang dilaksanakan oleh pemerintah, agar di dalam pemanfaatan ruang tepat sasaran dan sesuai dengan yang diharapkan.

Andri G. Wibisana (2017) mengemukakan bahwa campur tangan pemerintah dalam pengelolaan lingkungan merupakan hal yang sudah dianggap lazim dan biasa

6 Hardiyansyah, H. (2012). Analisis Kualitas Pelayanan Izin Mendirikan Bangunan pada Dinas Tata Kota di Kota Palembang. MIMBAR, Jurnal Sosial dan Pembangunan, 28(2), h.193.

7 Sutanto, T. (2014). Panduan Praktis Mengurus Sertifikat Tanah dan Perizinannya. Jakarta: Buku Pintar. h.179-180.

8 Handayani, Y. (2014). Hak Mantan Narapidana Sebagai Pejabat Publik Dalam Perspektif Hak Asasi Manusia. Jurnal RechtsVinding Online, Media Pembelajaran Hukum Nasional. h.1.

9 Hardjasoemantri, K.(1994) Hukum Lingkungan. Cetakan kedua. Yogyakarta: Gajah Mada University Press. 
ditemukan, sehingga campur tangan tersebut dianggap sebagai sesuatu yang semestinya ada. ${ }^{10}$

Sebagaimana disebutkan dalam Husen Alting (2013) cara pandang rezim kapitalisme yang melihat tanah sebagai barang komoditas, sehingga tanah dilepaskan dari ikatanikatan sosial yang melekat yang dapat mengakibatkan rusaknya sendi-sendi kehidupan masyarakat baik cepat atau lambat dan pada gilirannya akan menimbulkan gejolak perlawanan. ${ }^{11}$ Kondisi tersebut mengakibatkan tidak tercapainya tujuan peruntukan agraria untuk kesejahteraan masyarakat/petani, karena berimplikasi pada terjadinya degradasi kualitas tanah pertanian bahkan konflik pertanahan bak horizontal maupun vertikal.12

Mendirikan bangunan di atas tanah negara diperboleh kepada masyarakat, namun pada daerah tertentu negara melarang masyarakat untuk mendirikan bangunan yaitu daerah sempadan sungai. Larangan mendirikan bangunan di daerah sempadan sungai diatur dalam Peraturan Menteri Pekerjaan Umum Dan Perumahan Rakyat Republik Indonesia Nomor 28/PRT/M/2015 Tentang Penetapan Garis Sempadan Sungai Dan Garis Sempadan Danau. Kemudian aturan lebih lanjut tentang pemanfaatan sempadan sungai di atur oleh Peraturan Daerah. Akibatnya pada tahap perkembangan yang lebih kompleks timbul berbagai permasalahan lahan kota antara lain ketidakteraturan penggunaan tata ruang seperti tanah kota. ${ }^{13}$

Dalam hal penertiban bangunan yang berdiri tanpa izin, Pemerintah Kabupaten Aceh Besar dibawah tanggung jawab bupati memiliki kewenangan dalam melakukan pengaturan dan serta penertiban. Instansi yang diberikan kewenangan dalam melakukan kegiatan pelaksanaan penertiban tersebut yaitu Dinas Pekerjaan Umum Dan Penataan Ruang Kabupaten Aceh Besar dan Dinas Satpol PP dan Wilayatul Hisbah Aceh Besar.

Di Kabupaten Aceh Besar, larangan mendirikan bangunan di kawasan sempadan sungai diatur dalam Pasal 48 Ayat (4) Qanun Kabupaten Aceh Besar Nomor 4 Tahun 2013 Tentang Rencana Tata Ruang Wilayah Kabupaten Aceh Besar Tahun 2012-2032, dimana dijelaskan bahwa dilarang mendirikan bangunan pada kawasan sempadan sungai. Namun berdasarkan hasil observasi yang dilakukan penulis, bahwa terdapat sejumlah unit bangunan fungsi usaha yang berdiri di kawasan sempadan sungai di Desa Limpok, Kabupaten Aceh Besar. Tentunya bangunan yang berdiri tersebut tidak memiliki izin.

Berdasarkan hasil observasi penulis diatas menunjukkan bahwa dalam hal tersebut Pelaksanaan Penertiban bangunan yang berdiri disepanjang pelataran sempadan sungai di Kawasan Limpok Kabupaten Aceh Besar oleh Pemerintah khususnya dinas terkait belum terlaksana dengan efektif.

10 Wibisana, A. G. (2017). Campur Tangan Pemerintah Dalam Pengelolaan Lingkungan: Sebuah Penelusuran Teoretis Berdasarkan Analisis Ekonomi Atas Hukum (Economic Analysis of Law). Jurnal Hukum \& Pembangunan, 47(2), h.152.

11 Alting, H. (2013). Konflik Penguasaan Tanah di Maluku Utara: Rakyat Versus Penguasa dan Pengusaha. Jurnal Dinamika Hukum, 13(2),h.267.

12 Syamsudin, S. (2008). Beban masyarakat adat menghadapi hukum negara. Jurnal Fakultas Hukum UII, 15(3). h.346.

13 Hajati, S., Sekarmadji, A., \& Winarsih, S. (2014). Model Penyelesaian Sengketa Pertanahan Melalui Mediasi Dalam Mewujudkan Penyelesaian Yang Efisiensi dan Berkepastian Hukum. Jurnal Dinamika Hukum, 14(1), h.37. 
Berdasarkan permasalahan yang telah diuraikan pada latar belakang diatas, penulis tertarik untuk melakukan penelitian mengenai bagaimanakah proses pemberian izin mendirikan bangunan di Desa Limpok Kabupaten Aceh Besar dan bagaimana Pemerintah dalam upaya menertibkan bangunan yang berdiri tanpa izin di Sempadan sungai tanah milik negara di Kawasan Limpok Kabupaten Aceh Besar.

\section{Metode Penelitian}

Metode Penelitian yang digunakan yaitu penelitian yuridis empiris, penelitian ini dipilih untuk mengetahui fakta yang terjadi di lapangan. Pendekatan yang digunakan adalah pendekatan konseptual.

Teknik pengumpulan data yang dilakukan pada penelitian ini yaitu melakukan wawancara di lapangan terhadap seluruh masyarakat maupun pemerintah yang terkait dalam permasalahan, dan studi dokumen yang dilakukan untuk menghimpun data dengan melakukan penelaahan bahan-bahan kepustakaan yang meliputi bahan hukum primer, kemudian bahan hukum sekunder dan bahan hukum tersier. Dokumen ini merupakan sumber informasi yang penting yang berhubungan dengan Pelaksanaan Penertiban bangunan yang berdiri disepanjang pelataran sempadan sungai di Kawasan Limpok Kabupaten Aceh Besar.

\section{Hasil dan Pembahasan}

\subsection{Mekanisme Pemberian Izin Mendirikan Bangunan di Kawasan Sempadan Sungai Desa Limpok Kabupaten Aceh Besar}

Berdasarkan Pasal 1 Angka 8 Qanun Kabupaten Aceh Besar Nomor 14 Tahun 2010 Tentang Izin Mendirikan Bangunan, Izin Mendirikan Bangunan (IMB) adalah perizinan yang diberikan oleh Pemerintah Kabupaten kepada pemilik bangunan untuk membangun baru, mengubah, memperluas, mengurangi, dan/atau merawat bangunan sesuai dengan persyaratan administratif dan persyaratan teknis yang berlaku. Dengan demikian, jelas bahwa setiap masyarakat yang ingin mendirikan bangunan di kawasan aceh besar, terlebih dahulu wajib melakukan pengurusan izin dengan syarat-syarat yang telah ditentukan oleh Pemerintah Kabupaten Aceh Besar.

Dalam hal tersebut diatas apabila masyarakat tidak melaksanakan sebagaimana yang telah diatur, maka pemerintah berhak melaksanakan penegakan hukum terhadap pelanggaran yang dilakukan oleh masyarakat yang mendirikan bangunan tanpa izin di wilayah sempadan sungai desa limpok kabupaten Aceh Besar. Adapun sanksi yang dikenakan oleh masyarakat yaitu sanksi administratif dan sanksi pidana.

Adapun maksud dan tujuan dari pada izin mendirikan bangunan tersebut adalah agar terwujudnya bangunan yang fungsional dan sesuai dengan tata bangunan gedung yang serasi dan selaras dengan lingkungannya. Sebagaimana disebutkan pada Pasal 9 Angka (8) Qanun Kabupaten Aceh Besar Nomor 11 Tahun 2010 Tentang Izin Mendirikan Bangunan bahwa izin mendirikan bangunan diberikan terhadap kawasankawasan yang peruntukan tanahnya telah ditetapkan sesuai dengan rencana tata ruang wilayah kabupaten.

Berdasarkan hasil wawancara dengan Daud Sulaiman, yaitu salah seorang masyarakat yang mendirikan bangunan fungsi usaha di daerah sempadan sungai desa limpok 
kabupaten Aceh besar, bahwa bangunan dengan fungsi usaha yang didirikannya telah berdiri selama lebih kurang 6 (enam) tahun, dan bangunan tersebut berdiri diatas tanah yang menurut pengakuannya adalah tanah miliknya yang dibeli oleh salah seorang warga di desa limpok. Tanah tersebut dibeli dengan harga empat belas juta rupiah. Adapun pengakuan dari beliau bahwa usahanya tersebut telah mendapatkan izin dari geuchik desa limpok dan prosedur untuk mendapatkan izin hanya dengan melapor kepada geuchik. ${ }^{14}$ Daud memberikan keterangan bahwa selama menjalankan usahanya belum pernah sama sekali mendapatkan himbauan untuk melaksanakan pengurusan izin mendirikan bangunan.

Kemudian hasil wawancara dengan Rina, yaitu salah seorang pemilik bangunan gedung dengan fungsi usaha perdagangan bakso yang juga mendirikan bangunan di atas tanah di kawasan sempadan sungai. Rina menjelaskan bahwa bangunan dengan fungsi usaha perdagangan bakso tersebut telah didirikan selama 2(dua) tahun, dan bangunan usaha miliknya tersebut didirikan di atas tanah yang menurut pengakuannya adalah disewa selama 5 (lima) tahun. Selama rina menjalankan usahanya tersebut, rina mengaku tidak melakukan pengurusan izin terhadap bangunan fungsi usaha yang didirikannya tersebut. ${ }^{15}$

Berdasarkan pernyataan beberapa orang pemilik bangunan fungsi usaha yang mendirikan bangunan di kawasan sempadan sungai di desa limpok kabupaten Aceh besar tersebut menggambarkan dengan jelas, bahwa selama ini mereka mendirikan bangunan dengan fungsi usaha di kawasan tersebut tidak memiliki izin yang dikeluarkan secara resmi oleh pemerintah yang berwenang, namun hanya diperoleh secara lisan saja oleh geuchik. Dalam hal tersebut sangat jelas bahwa pemilik bangunan jenis fungsi usaha tersebut tidak dapat surat izin mendirikan bangunan yang dikeluarkan secara resmi oleh pemerintah sebab tidak dapat memenuhi syarat yang telah ditentukan berdasarkan Pasal 18 Qanun Kabupaten Aceh Besar Nomor 14 Tahun 2010 Tentang Izin Mendirikan Bangunan. adapun syarat yang disebutkan yaitu

\section{a. Persyaratan Administrasi}

1. Surat permohonan yang ditandatangani oleh pemohon diatas materai dan diketahui oleh Geuchik setempat dimana lokasi bangunan akan dibangun;

2. Fotokopi kartu tanda penduduk (KTP) pemohon;

3. Surat rekomendasi dari camat setempat;

4. Fotokopi sertifikat dan surat keterangan pendaftaran tanah (SKPT) yang dikeluarkan oleh Badan Pertanahan Nasional Kabupaten Aceh Besar;

5. Apabila tanah belum bersertifikat harus dilampirkan surat bukti atas hak tanah lainnya yang disahkan oleh pejabat

6. Apabila tanah belum bersertifikat harus dilampirkan surat bukti atas hak tanah lainnya yang disahkan oleh pejabat yang berwenang dan pemohon terlebih dahulu harus mendaftarkan tanahnya pada Badan Pertanahan Nasional Kabupaten Aceh Besar untuk diterbitkan SKPT;

7. Fotokopi surat tanda lunas pajak bumi dan bangunan (PBB) tahun terakhir;

14 Daud Sulaiman, Pemilik Bangunan Fungsi Usaha Di Kawasan Sempadan Sungai Desa Limpok Kabupaten Aceh Besar, wawancara, 1 November 2018.

15 Rina, Pemilik Bangunan Fungsi Usaha Di Kawasan Sempadan Sungai Desa Limpok Kabupaten Aceh Besar, wawancara, 1 November 2018. 
8. Surat pernyataan permohonan bahwa tanah tidak dalam sengketa yang diketahui oleh geuchik setempat (khusus untuk tanah yang belum bersertifikat atau telah berakhir haknya);

9. Surat perjanjian atau surat kuasa yang disahkan oleh pejabat yang berwenang (bila pemohon bukan pemilik tanah);

10. Surat pernyataan pelepasan hak dari pemilik tanah terhadap tanah yang termasuk dalam bagian garis sempadan bangunan (GSB)/ rencana perluasan jalan, untuk bangunan dengan fungsi usaha;

11. Fotokopi IMB lama beserta lampirannya (khusus untuk rehabilitasi/renovasi/ penambahan bangunan).

b. Persyaratan teknis

1. Saran perencanaan / keterangan rencana peruntukan yang diterbitkan oleh instansi teknis terkait;

2. Gambar rencana bangunan(denah, tampak, potongan) dan spesifikasi teknis yang dibuat oleh konsultan perencana;

3. Perhitungan struktur konstruksi dan gambar detail struktur yang dibuat oleh konsultan perencana (khusus untuk bangunan bertingkat)

4. Bangunan khusus (kawasan industri, perhotelan, perumahan real estate, kawasan parawisata, pelabuhan dan bangunan dengan ketinggian 60 meter atau lebih diwajibkan melengkapi analisa dampak lingkungan (AMDAL);

5. Fotokopi sertifikat tanah dan surat pelunasan pajak bumi dan bangunan (PBB) tahun terakhir;

6. Fotokopi surat ukur tanah.

Berdasarkan persyaratan sebagaimana telah disebutkan diatas, tentunya pemilik bangunan gedung yang mendirikan bangunan di kawasan sempadan sungai di Desa limpok kabupaten Aceh besar tidak dapat melengkapinya, sebab tanah di sempadan sungai Desa limpok kabupaten Aceh besar merupakan tanah milik negara, dimana tanah milik negara tersebut dihimbau larangan untuk mendirikan bangunan di atasnya. Adapun ketentuan yang membolehkan masyarakat memanfaatkan tanah tersebut, kecuali larangan sebagaimana disebutkan pada Pasal 22 Ayat (2) Peraturan Menteri Pekerjaan Umum Dan Perumahan Rakyat Republik Indonesia Nomor 28/PRT/M/2015 Tentang Penetapan Garis Sempadan Sungai Dan Garis Sempadan Danau. Dimana disebutkan bahwa dilarang menanam tanaman selain rumput, mendirikan bangunan, dan mengurangi dimensi tanggul.

\subsection{Faktor yang Menjadi Hambatan Pemerintah dalam menertibkan Bangunan yang Berdiri di Kawasan Sempadan Sungai Desa Limpok Kabupaten Aceh Besar}

Ketentuan larangan mendirikan bangunan tanpa izin di Kabupaten Aceh Besar diatur pada Pasal 26 Ayat (1) Qanun Kabupaten Aceh Besar Nomor 14 Tahun 2010 Tentang Izin Mendirikan Bangunan, dimana disebutkan bahwa dilarang mendirikan bangunan tanpa izin mendirikan bangunan. artinya seluruh masyarakat yang ingin mendirikan bangunan di Kawasan Desa Limpok Aceh Besar wajib mengurus izin mendirikan bangunan terlebih dahulu apabila ingin mendirikan bangunan. Namun di lapangan ditemui bahwa masyarakat yang mendirikan bangunan di kawasan sempadan sungai 
di kawasan desa limpok kabupaten Aceh Besar tidak memiliki izin, sebab di kawasan sempadan sungai terdapat larangan untuk mendirikan bangunan. dengan demikian masyarakat yang mendirikan bangunan di sempadan sungai tersebut telah melakukan pelanggaran hukum.

Berdasarkan keterangan dari sekretaris desa limpok Syukri Ibrahim, bahwa bangunan dengan fungsi usaha yang berdiri di Kawasan sempadan sungai di Desa Limpok Kabupaten Aceh Besar telah lama berdiri. Menurut keterangan beliau, pada awalnya tanah di sempada sungai Di kawasan desa limpok tersebut merupakan tanah kosong, artinya belum ada pemanfaatan diatas tanah tersebut. Kemudian pihak dari Kementerian Pekerjaan Umum Direktorat Jenderal Sumber Daya Air Balai Wilayah sungai sumatera 1 mendatangi Geuchik Desa tersebut, kemudian pihak PU tersebut memberikan kesempatan kepada masyarakat untuk menggunakan tanah di sempadan sungai desa limpok, namun dengan ketentuan tidak boleh mendirikan bangunan di atasnya, jadi hanya dibenarkan untuk menanam tanaman seperti jagung, pisang, dan jenis-jenis tanaman yang tidak keras. Namun lama kelamaan masyarakat yang mendapatkan pembagian tanah tersebut mulai mendirikan bangunan-bangunan yang digunakan untuk fungsi usaha. Adapun usaha yang dijalankan yaitu usaha warung kopi, pembibitan ikan, kios, warung bakso, dan lain sebagainya. Aparatur gampong merasa kewalahan dalam melakukan teguran atau tindakan, sebab takut terjadi hal yang tidak diinginkan. Namun menurut pendapat sekretaris desa tersebut, kendala yang dihadapi seharusnya dapat diatasi secara langsung oleh pemerintah, akan tetapi tidak pernah ada tindakan secara tegas bahkan tidak pernah sama sekali pemerintah terkait datang untuk melakukan teguran. Hanya saja tiang himbauan larangan yang berisi ancaman pidana yang dipasangkan, namun tidak ada tindakan sesuai ancaman yang dipasang. ${ }^{16}$

\section{Kesimpulan}

Tahapan mekanisme izin mendirikan bangunan yang diterapkan oleh Pemerintah tidak berjalan sesuai aturan. Masih terdapat bangunan fungsi usaha yang berdiri di sempadan sungai desa limpok Kabupaten Aceh Besar tidak memiliki izin, artinya masyarakat melakukan pelanggaran terhadap hukum yang diberlakukan. Dalam hal ini sudah sepatutnya pemerintah terkait melakukan tindakan secara tegas agar masyarakat tidak melakukan pelanggaran hukum.

Belum ada tindakan tegas maupun upaya serius yang dilakukan oleh pemerintah dalam melakukan tindakan terhadap bangunan tanpa izin yang berdiri di kawasan sempadan sungai desa limpok Kabupaten Aceh Besar, sehingga masyarakat terus melakukan pelanggaran hukum. Dalam hal ini pemerintah harus melaksanakan kewajiban dalam melaksanakan tindakan hukum terhadap pelanggaran yang dilakukan oleh masyarakat. Sebab apabila upaya tersebut tidak dilakukan, maka masyarakat akan lebih leluasa dalam melakukan pelanggaran hukum.

16 Syukri Ibrahim, Sekretaris Desa Limpok Kabupaten Aceh Besar, wawancara, 9 November 2018. 


\section{Daftar Pustaka}

$\underline{\text { Buku }}$

Fuady, M, (2011). Teori Negara Hukum Modern Rechtstaat, Bandung,: PT. Reflika Aditama.

Hardjasoemantri, K. (1994). Hukum Lingkungan. Cetakan kedua. Yogyakarta: Gajah Mada University Press.

Limbong, B. (2012). Hukum Agraria Nasional, Jakarta: Margaretha Pustaka.

Santoso, U. (2009). Hukum agraria dan Hak-hak Atas Tanah. Jakarta: Kencana.

Sutanto, T. (2014).Panduan Praktis Mengurus Sertifikat Tanah dan Perizinannya. Jakarta: Buku Pintar.

\section{Jurnal}

Alting, H. (2013). Konflik Penguasaan Tanah di Maluku Utara: Rakyat Versus Penguasa dan Pengusaha. Jurnal Dinamika Hukum, 13(2), 266-282. http://dx.doi.org/10.20884/1.jdh.2013.13.2.209

Moeljono, M., Koeswahyono, I., Widiarto, A. E., Sutoyo, S., \& Mualiffien, D. M. (2012). Kajian Yuridis Tentang Pengelolaan Tanah Penguasaan Pemerintah Kota Malang Yang Disewa Oleh Pihak Ketiga. Jurnal Hukum \& Pembangunan, 42(2), 183-198. $\quad$ http://dx.doi.org/10.21143/jhp.vol42.n2

Santoso, U. (2013). Kewenangan Pemerintah Daerah dalam Penguasaan Atas Tanah. Jurnal Dinamika Hukum, 13(1), 99-108. http://dx.doi.org/10.20884/1.jdh.2013.13.1.159

Handayani, Y. (2014). Hak Mantan Narapidana Sebagai Pejabat Publik Dalam Perspektif Hak Asasi Manusia. Jurnal RechtsVinding Online, Media Pembelajaran Hukum Nasional. 1-5.

Hardiyansyah, H. (2012). Analisis Kualitas Pelayanan Izin Mendirikan Bangunan pada Dinas Tata Kota di Kota Palembang. MIMBAR, Jurnal Sosial dan Pembangunan, 28(2), 191-199. https://doi.org/10.29313/mimbar.v28i2.355

Hajati, S., Sekarmadji, A., \& Winarsih, S. (2014). Model Penyelesaian Sengketa Pertanahan Melalui Mediasi Dalam Mewujudkan Penyelesaian Yang Efisiensi dan Berkepastian Hukum. Jurnal Dinamika Hukum, 14(1), 36-48. http://dx.doi.org/10.20884/1.jdh.2014.14.1.275

Syamsudin, S. (2008). Beban masyarakat adat menghadapi hukum negara. Jurnal Fakultas Hukum UII, 15(3). 338-351.

Wibisana, A. G. (2017). Campur Tangan Pemerintah Dalam Pengelolaan Lingkungan: Sebuah Penelusuran Teoretis Berdasarkan Analisis Ekonomi Atas Hukum (Economic Analysis of Law). Jurnal Hukum \& Pembangunan, 47(2), 151-182. http://dx.doi.org/10.21143/jhp.vol47.n2 